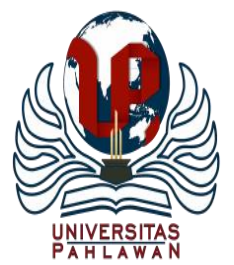

Edukatif : Jurnal Ilmu Pendidikan Volume 3 Nomor 4 Tahun 2021 Halm 2099 - 2107

EDUKATIF: JURNAL ILMU PENDIDIKAN

Research \& Learning in Education

https://edukatif.org/index.php/edukatif/index

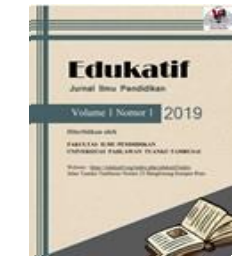

\title{
Meningkatan Hasil Belajar Siswa melalui Penerapan Strategi Pembelajaran Card Sort di Madrasah Ibtidaiyah
}

\author{
Deni Indrawan ${ }^{1 凶}$, Ichsan $^{2}$ \\ Universitas Islam Negeri Sunan Kalijaga, Indonesia ${ }^{1,2}$ \\ E-mail : deniindrawan1998@ gmail.com ${ }^{1}$, ichsandjalal@ gmail.com ${ }^{2}$
}

\begin{abstract}
Abstrak
Tujuan penelitian ini untuk meningkatkan hasil belajar IPA di Kelas III MI Matla'ul Atfal. Penelitian ini merupakan Penelitian Tindakan Kelas (PTK) yang terdiri atas 3 siklus yang setiap siklusnya merupakan rangkaian kegiatan yang terdiri atas 4 tahapan yaitu perencanaan, pelaksanaan, pengamatan/observasi dan refleksi. Subjek penelitian ini siswa kelas III sejumlah 26 siswa, terdiri atas 14 siswa laki-laki dan 12 siswa perempuan. Instrumen pengumpulan data berupa tes tertulis, lembar observasi dan dokumentasi. Berdasarkan hasil penelitian ini menunjukkan bahwa proses pembelajaran IPA dengan menerapkan strategi card sort membantu siswa untuk memahami materi dengan mudah, pembelajaran menyenangkan, melibatkan siswa sehingga keaktifan siswa terlihat dalam proses pembelajaran. Hasil belajar siswa mengalami perubahan yang sangat baik pada setiap siklusnya dilihat dari hasil nilai rata-rata setiap siklus yang mengalami peningkatan. Peningkatan hasil belajar IPA dengan penerapan strategi card sort sangat baik. Hal ini dapat dibuktikan dengan adanya ketuntasan individual dalam belajar pada setiap siklusnya. Pada pra siklus 38,46\%, naik menjadi 50\%, pada siklus I 76,92\% pada siklus II dan 100\% pada siklus III. Hasil kemampuan belajar siswa meningkat, pada intinya upaya meningkatkan hasil belajar IPA dengan penerapan strategi card sort sangat berpengaruh untuk siswa Sekolah Dasar.
\end{abstract}

Kata Kunci: Hasil Belajar, IPA, Card Sort

\begin{abstract}
The purpose of this study was to improve the science learning outcomes in Class III MI Matla'ul Atfal. This research is a Classroom Action Research (PTK) which consists of 3 cycles, each of which is a series of activities consisting of 4 stages, namely planning, implementing, observing, and reflecting. The subjects of this study were 26 grade III students, consisting of 14 male students and 12 female students. The data collection instruments were written tests, observation sheets, and documentation. Based on the results of this study, it shows that the science learning process by applying the card sort strategy helps students to understand the material easily, learning is fun, involving students so that student activity is seen in the learning process. Student learning outcomes have changed very well in each cycle seen from the results of the average value of each cycle that has increased. The improvement of science learning outcomes by implementing the card sort strategy is very good. This can be proven by the existence of individual completeness in learning in each cycle. In the pre-cycle 38.46\%, increased to 50\%, 76.92\% in the first cycle in the second cycle, and 100\% in the third cycle. The results of students' learning abilities have increased, in essence, efforts to improve science learning outcomes by implementing the card sort strategy are very influential for elementary school students.
\end{abstract}

Keywords: learning Outcomes, Science, Card Sort

Copyright (c) 2021 Deni indrawan, Ichsan

Corresponding author:

Email : deniindrawan1998@gmail.com

DOI : https://doi.org/10.31004/edukatif.v3i4.1033

ISSN 2656-8063 (Media Cetak)

ISSN 2656-8071 (Media Online)

Edukatif : Jurnal Ilmu Pendidikan Vol 3 No 4 Tahun 2021 p-ISSN 2656-8063 e-ISSN 2656-8071 


\section{PENDAHULUAN}

Pendidikan merupakan usaha pengembangan kualitas diri manusia dalam segala aspeknya. Pendidikan sebagai aktivitas yang disengaja untuk mencapai tujuan tertentu dan melibatkan berbagai faktor yang saling berkaitan antara satu dan lainnya, sehingga membentuk satu sistem yang saling mempengaruhi (Tatang S, 2012). Perkembangan zaman yang terus berputar membuat adanya pembaharuan. Dengan cukup banyaknya terobasan yang baru di dunia pendidikan, seperti halnya dalam penerapan model, strategi dan masih banyak yang lainnya. Kebutuhan ini yang sudah mendorong akan adanya pembaharuan yang ditunjukan bagi siswa dan dalam rangka perbaikan belajar. Maka dari itu, lembaga pendidikan harus mampu serta sudah mengantisipasi perkembangan yang ada guna untuk bisa lebih mengupayakan kebutuhan dan perkembangan siswa, zaman, dan situasi dan kondisi siswa (Yani, 2012).

Salah satu permasalahan yang sering dihadapi dalam proses pembelajaran adalah adanya kelemahan pada saat pelaksanaan proses pembelajaran berlangsung yang diterapkan guru. Maka dari itu, peranan strategi pembelajaran sebagai suatu upaya untuk menciptakan proses pembelajaran yang efektif. Strategi pembelajaran dijadikan sebagai salah satu upaya yang digunakan oleh guru untuk menciptakan suatu proses belajar mengajar agar tujuan yang sudah ditetapkan bisa tercapai dengan baik.

Berdasarkan observasi yang peneliti lakukan di kelas III MI Matla'ul Atfal, pada saat proses pembelajaran IPA berlangsung banyak siswa yang kurang antusias dan condong kurang aktif dalam proses pembelajaran serta mengacuhkan guru yang menyampaikan pelajaran. Akibatnya siswa tidak bisa menyelesaikan masalah dan kesannya kesulitan memahami pembelajaran IPA. Hal ini dikarenakan strategi serta media pembelajaran yang kurang mendukung sehingga hasil belajar pun juga rendah, ini terlihat bahwa baru 10 siswa atau 38,46\% yang memenuhi kriteria ketuntasan minimal (KKM) 65, dan yang belum tuntas sebanyak 16 siswa atau 61,53\% dari 26 siswa. Dengan demikian hasil belajar siswa dikatakan masih rendah dan perlu ditingkatkan. Hasil belajar adalah suatu perubahan perilaku secara keseluruhan mencakup aspek kognitif, efektif dan psikomotorik (Surya, 2003).

Hasil belajar meningkat tidak terlepas adanya keaktifan siswa pada saat proses pembelajaran berlangsung. Berhasil tidaknya suatu pembelajaran di sekolah bergantung pada keterlibatan siswa dan penerapan strategi pembelajaran dalam proses belajar mengajar. Penerapan strategi sangat membantu pada saat pembelajaran. Salah satu usaha yang dapat dilakukan adalah bagaimana menempatkan strategi pembelajaran sebagai salah satu komponen yang ikut andil dalam keberhasilan proses pembelajaran.

Maka dari itu, pembelajaran IPA harus dilaksanakan dengan baik dan harus dijadikan perhatian lebih agar menjadi bekal kuat bagi siswa dan pembelajaran IPA harus dijadikan pondasi kuat buat jenjang berikutnya dengan diperkuat pada saat pembelajaran di sekolah dasar/MI. Selain itu IPA juga memberikan beberapa pengalaman belajara lain bagi siswa, seperti pengalaman belajar karakter yang nantinya akan berpengaruh kepaedea keberhasilan siswa dalam hubungan dengan sesama manusia dan alam (Surya, 2010).

Belajar yang diaplikasikan dalam pembelajaran IPA adalah perumusan tujuan-tujuan pendidikan yang sesuai dengan dimensi kognitif (mengingat, memahami, mengaplikasi, menganalisis, mengevaluasi, dan mencipta) dan dimensi pengetahuan (faktual, konseptual, prosedural, dan metakognitif) (Wisudawati, 2014). IPA merupakan pengetahuan teoritis yang diperoleh atau disusun dengan cara yang khas atau khusus, yaitu dengan melakukan observasi, eksperimentasi, penyimpulan, penyusunan teori, eksperimentasi, observasi dan demikian seterusnya kait mengkait antara cara yang satu dengan cara yang lain (Rahma., 1998). Keberhasilan mata pelajaran IPA sangat berpengaruh pada kemampuan guru dalam mengelola proses pembelajaran. Seorang guru ketika mengajar selain menguasai bahan ajar juga dituntut dapat mengajar dengan menggunakan strategi, model dan media pembelajaran sesuai bahan/materi yang diajarkan (Fauzi, 2013).

Dari berbagai permasalahan diatas, maka dapat ditarik kesimpulan bahwa penyebab utama rendahnya hasil belajar siswa adalah proses belajar mengajar masih berpusat pada guru (Teacher Centered Learning) 
sehingga siswa tidak terlibat aktif dalam pembelajarandan faktor kurangnya pembaharuan strategi yang dipakai guru dalam proses pembelajaran. Oleh karena itu dibutuhkan peran guru untuk dapat menerapkan pembelajaran yang melibatkan partisipasi siswa sehingga kegiatan belajar mengajar menjadi menyenangkan dan tidak membuat jenuh.

Melihat permasalahan tersebut, maka perlu diterapkan suatu strategi pembelajaran yang dapat meningkatkan hasil belajar siswa dalam proses pembelajaran yaitu dengan menerapkan strategi pembelajaran Card Sort. Strategi ini ialah strategi yang memanfaatkan media kartu yang dipotong menjadi beberapa bagian yang di dalam kartu tersebut berisi materi pelajaran dan informasi (Raisul, 2006). Tujuan dari strategi pembelajaran Card Sort ini adalah untuk memperkuat daya ingat atau recoll terhadap materi pelajaran yang telah dipelajari siswa serta mengaktifkan setiap individu sekaligus membangun kerjasama kelompok dalam belajar. Media pembelajaran merupakan salah satu faktor yang berperan penting selama proses pembelajaran. Guru menggunakan media sebagai perantara dalam menyampaikan materi agar dapat dipahami oleh peserta didiknya dengan baik (Wahyuningtyas \& Sulasmono, 2020).

Berdasarkan uraian latar belakang masalah di atas maka peneliti tertarik untuk melakukan penelitian dengan judul "Peningkatan Hasil Belajar Siswa Dalam Mata Pelajaran IPA Melalui Penerapan Stategi Pembelajaran Card Sort Di Kelas III MI Matla'ul Atfal".

\section{METODE PENELITIAN}

Penelitian ini menggunakan metode Penelitian Tindakan Kelas (PTK) atau Classroom Action Research (CAR). PTK adalah penelitian yang bentuknya reflektif dengan cara melakukan tindakan tertentu supaya bisa memperbaiki dan juga meningkatkan praktik pembelajaran di kelas agar lebih lebih profesional (Mahmud, 2008). PTK yang digunakan adalah sebuah model dari rancanagan Kemmis \& Taggart yang di dalam alurnya itu terdapat empat proses yang harus dilalui, meliputi: perencanaan (Planning), tindakan (Action), observasi ( Observe) dan refleksi ( Reflection) (Aqib, 2009). Penelitian ini dilakukan di Madrasah Ibtidaiyah Matla'ul Atfal Kec. Cibiru, Kota Bandung. Dilaksanakan pada bulan Agustus tahun 2019. Subjek dalam penelitian ini melibatkan siswa kelas III MI Mala'ul Atfal dengan jumlah siswa laki-laki 14 orang dan siswa perempuan 12 orang, maka jumlah keseluruhan siswa adalah 26 orang. Instrument penelitian ini menggunakan Lembar Obsevasi, Tes Tertulis, Dokumentasi. Analisis data menggunakan data secara deskriptif kualitatif.

\section{HASIL DAN PEMBAHASAN PENELITIAN}

Pada siklus 1 menunjukan 13 orang siswa sudah tuntas dan 13 orang siswa lainnya belum tuntas. Hal itu disebabkan karena siswa tidak memperhatikan guru selama proses pembelajaran dan penggunaan alat peraga dalam proses pembelajaran belum maksimal. Suatu kelas dikatakan tuntas belajarnya apabila terdapat $65 \%$ siswa yang tuntas belajarnya. Sedangkan dalam siklus I ini hanya 50\% siswa yang tuntas belajarnya. Maka dapat disimpulkan bahwa hasil belajar siswa pada siklus I dengan penerapan strategi Card Sort belum tuntas.

Hasil belajar siswa pada siklus I tindakan I menunjukan 17 orang siswa sudah tuntas dan 9 orang siswa lainnya belum tuntas. Hal itu disebabkan karena siswa tidak memperhatikan guru selama proses pembelajaran dan penggunaan alat peraga dalam proses pembelajaran belum maksimal. Suatu kelas dikatakan tuntas belajarnya apabila terdapat $65 \%$ siswa yang tuntas belajarnya. Pada siklus ini terdapat $65,38 \%$ siswa yang tuntas belajarnya. Maka dapat disimpulkan bahwa hasil belajar siswa pada siklus I dengan penerapan strategi Card Sort tuntas.

Tabel 1

Data Hasil Evaluasi Siklus I Tindakan I

\begin{tabular}{clcc}
\hline No & Nama & Nilai & Ket \\
\hline 1 & AN & 70 & Tuntas \\
\hline
\end{tabular}


2102 Meningkatan Hasil Belajar Siswa Melalui Penerapan Strategi Pembelajaran Card Sort di Madrasah Ibtidaiyah - Deni indrawan, Ichsan

DOI: https://doi.org/10.31004/edukatif.v3i4.1033

\begin{tabular}{|c|c|c|c|}
\hline 2 & AS & 70 & Tuntas \\
\hline 3 & AA & 70 & Tuntas \\
\hline 4 & $\mathrm{AH}$ & 60 & Tidak Tuntas \\
\hline 5 & $\mathrm{AD}$ & 80 & Tuntas \\
\hline 6 & $\mathrm{CM}$ & 70 & Tuntas \\
\hline 7 & $\mathrm{CS}$ & 70 & Tuntas \\
\hline 8 & FM & 70 & Tuntas \\
\hline 9 & $\mathrm{FN}$ & 70 & Tuntas \\
\hline 10 & GA & 60 & Tidak Tuntas \\
\hline 11 & IM & 70 & Tuntas \\
\hline 12 & JS & 60 & Tidak Tuntas \\
\hline 13 & $\mathrm{KR}$ & 70 & Tuntas \\
\hline 14 & MY & 70 & Tuntas \\
\hline 15 & MA & 60 & Tidak Tuntas \\
\hline 16 & MF & 80 & Tuntas \\
\hline 17 & MF & 70 & Tuntas \\
\hline 18 & MR & 70 & Tuntas \\
\hline 19 & $\mathrm{NH}$ & 80 & Tuntas \\
\hline 20 & NA & 60 & Tidak Tuntas \\
\hline 21 & QN & 80 & Tuntas \\
\hline 22 & $\mathrm{RS}$ & 60 & Tidak tuntas \\
\hline 23 & SG & 70 & Tuntas \\
\hline 24 & TR & 60 & Tidak Tuntas \\
\hline 25 & $\mathrm{ZZ}$ & 60 & Tidak Tuntas \\
\hline \multirow[t]{4}{*}{26} & ZI & 60 & Tidak Tuntas \\
\hline & Jumlah & 1.780 & \\
\hline & Rata-rata & 68,46 & \\
\hline & $\begin{array}{l}\text { Ketuntasan } \\
\text { Klasikal }\end{array}$ & $65,38 \%$ & \\
\hline
\end{tabular}

Menurut (Sudjiono, 2005), Pengukuran presentase ketuntasan belajar siswa secara klasikal dapat menggunakan rumus sebagai berikut:

$$
\mathrm{P}=\frac{\text { jumlah siswa yang tuntas belajar }}{\text { jumlah seluruh siswa }} \times 100 \%
$$

Tabel 2

Kriteria Ketuntasan Maksimal

\begin{tabular}{ll}
\hline Kriteria & Kategori \\
\hline$\geq 80 \%$ & Sangat tinggi \\
\hline $60 \%-79 \%$ & Tinggi \\
\hline $40 \%-59 \%$ & Sedang \\
\hline $20 \%-39 \%$ & Rendah \\
\hline$<20 \%$ & Sangat rendah \\
\hline
\end{tabular}

Dari data nilai hasil belajar siswa di siklus II menunjukan adanya peningkatan yang signifikan yaitu 20 siswa telah mencapai ketuntasan belajar namun masih ada 6 siswa yang belum tuntas belajar karena motivasi untuk belajar yang kurang sehingga perlu pendampingan dari guru untuk dapat mengikuti proses pembelajaran 
dengan baik. Pada siklus ini hampir seluruh siswa berperan aktif dalam pembelajaran. meskipun pada siklus ini sebagian besar siswa telah tuntas hasil belajarnya yaitu 76,92\%, namun masih ada beberapa siswa yang belum tuntas dalam siklus ini. Dapat disimpulkan bahwa hasil belajar dalam siklus ini dinyatakan

Hasil persentase atau ketuntasan belajar siswa pada siklus III ini 100\%. Dengan demikian pembelajaran pada siklus III ini dinyatakan berhasil karena hasilnya di atas rata-rata. Seperti dikatakan siswa tuntas belajar apabila jumlah siswa yang menjawab dengan benar lebih dari $65 \%$ dan suatu kelas dikatakan tuntas belajarnya jika dalam kelas tersebut terdapat $65 \%$ siswa yang tuntas belajar. Maka dapat disimpulkan bahwa pembelajaran dengan penerapan strategi Card Sort pada siklus III berhasil dengan seluruh siswa tuntas belajar.

Setelah melaksanakan pembelajaran di kelas III MI Matla'ul Atfal Kota Bandung hasil belajar IPA khusunya materi pertumbuhan Hewan dengan menerapkan strategi pembelajaran card sort setiap siklusnya mengalami peningkatan. Berikut disajikan data hasil evaluasi belajar siswa mulai dari siklus I, siklus II dan siklus III.

Tabel 3

Data Evaluasi Belajar Siswa Seluruh Siklus

\begin{tabular}{|c|c|c|c|c|}
\hline \multirow{2}{*}{ No } & \multirow{2}{*}{ Nama } & \multicolumn{3}{|c|}{ Nilai } \\
\hline & & Siklus I & Siklus II & Siklus III \\
\hline 1 & AN & 60 & 70 & 80 \\
\hline 2 & AS & 70 & 70 & 80 \\
\hline 3 & AA & 70 & 80 & 85 \\
\hline 4 & $\mathrm{AH}$ & 60 & 65 & 80 \\
\hline 5 & $\mathrm{AD}$ & 80 & 85 & 95 \\
\hline 6 & $\mathrm{CM}$ & 60 & 70 & 80 \\
\hline 7 & $\mathrm{CS}$ & 60 & 70 & 80 \\
\hline 8 & FM & 70 & 70 & 80 \\
\hline 9 & FN & 70 & 70 & 80 \\
\hline 10 & GA & 60 & 70 & 80 \\
\hline 11 & IM & 70 & 80 & 85 \\
\hline 12 & JS & 60 & 70 & 80 \\
\hline 13 & KR & 70 & 80 & 85 \\
\hline 14 & MY & 70 & 80 & 80 \\
\hline 15 & MA & 60 & 65 & 80 \\
\hline 16 & MF & 80 & 85 & 95 \\
\hline 17 & MF & 60 & 70 & 80 \\
\hline 18 & MR & 70 & 80 & 85 \\
\hline 19 & $\mathrm{NH}$ & 80 & 85 & 85 \\
\hline 20 & NA & 60 & 70 & 70 \\
\hline 21 & QN & 80 & 85 & 90 \\
\hline 22 & $\mathrm{RS}$ & 60 & 65 & 70 \\
\hline 23 & SG & 70 & 70 & 80 \\
\hline 24 & TR & 60 & 65 & 80 \\
\hline 25 & $\mathrm{ZZ}$ & 60 & 65 & 80 \\
\hline 26 & ZI & 60 & 65 & 70 \\
\hline
\end{tabular}


2104 Meningkatan Hasil Belajar Siswa Melalui Penerapan Strategi Pembelajaran Card Sort di Madrasah Ibtidaiyah - Deni indrawan, Ichsan

DOI: https://doi.org/10.31004/edukatif.v3i4.1033

\begin{tabular}{lccc}
\hline Jumlah & 1.730 & 1900 & $\mathbf{2 . 1 1 5}$ \\
\hline Rata-Rata & $\mathbf{6 6 , 5 3}$ & $\mathbf{7 3 , 0 7}$ & $\mathbf{8 1 , 3 4}$ \\
\hline Presentase & $\mathbf{5 0 \%}$ & $\mathbf{7 6 , 9 2 \%}$ & $\mathbf{1 0 0 \%}$ \\
\hline
\end{tabular}

Data di atas menunjukan sebagian besar siswa mengalami peningkatan dalam hasil belajar dalam setiap siklusnya. Ada beberapa siswa yang belum tuntas belajar atau belum memenuhi KKM yang ditentukan karena kurang berkonsentrasi serta kurangnya motivasi untuk mengikuti kegiatan pembelajaran sehingga perlu pemdampingan lebih dari guru agar dapat memahami dan mengerti terhadap materi yang disampaikan. Namun pada siklus III, semua siswa mengalami ketuntasan pada hasil belajar.

Hasil data tersebut menunjukan rata-rata hasil belajar siswa mulai dari siklus I yaitu 66,53 dengan kategori "cukup", rata-rata hasil belajar pada siklus II yaitu 73,07 dengan kategori "baik" dan rata-rata hasil belajar siswa pada siklus III yaitu 81,34 dengan masuk kategori "Sangat Baik". Hasil data rata-rata belajar siswa dalam setiap siklus dapat diinterpretasikan dalam grafik sebagai berikut:

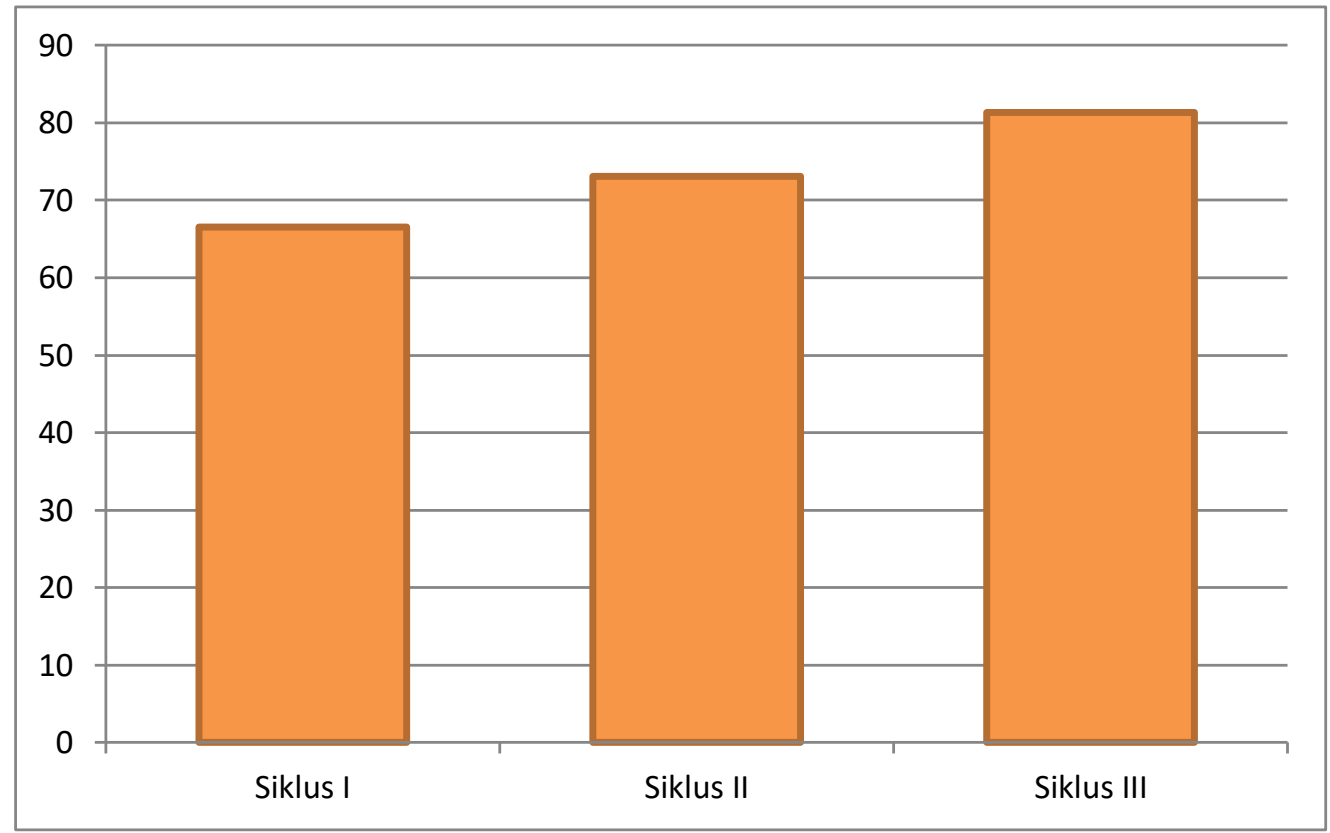

Grafik 1. Data Rata-Rata Hasil Belajar Siswa Seluruh Siklus

Selain hasil rata-rata belajar siswa yang mengalami peningkatan dalam setiap siklusnya, persentase atau ketuntasan klasikal pun mengalami hal peningkatan dalam setiap siklusnya. Pada siklus I hasilnya 50\% dengan kategori "Sedang", pada siklus II hasilnya 76,92\% dengan kategori "Baik" dan pada siklus III hasilnya $100 \%$ dengan kategori "Sangat Baik". Berikut disajikan grafik hasil presentase atau ketuntasan klasikal pada saat siklus I, siklus II dan siklus III sebagai berikut: 


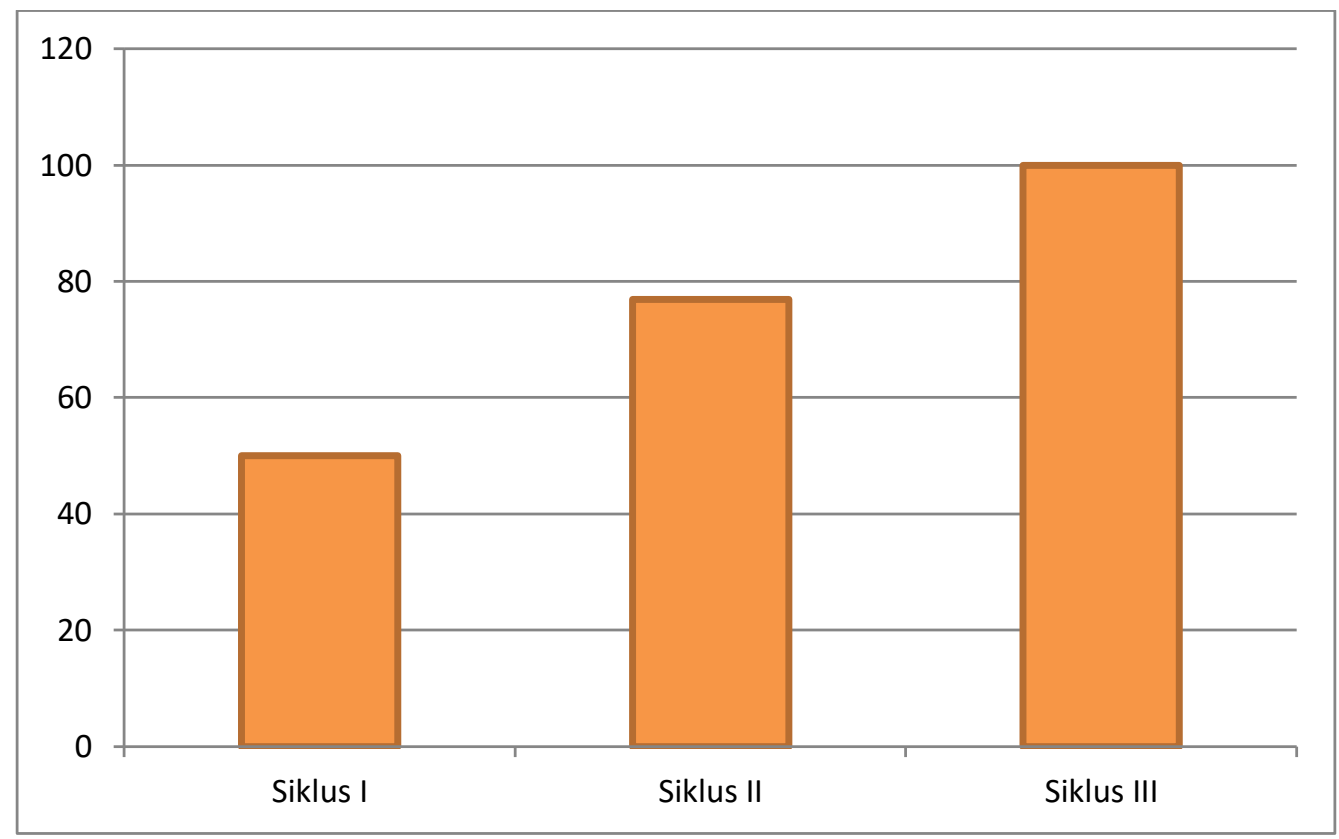

Grafik 2. Data Ketuntasan Klasikal Seluruh Siklus

Dengan demikian pembelajaran IPA materi pertumbuhan dan perkembangan hewan di kelas III MI Matla'ul Atfal Kota Bandung mengalami peningkatan yang baik dalam belajar. Keberhasilan dalam peningkatan hasil belajar siswa tidak terlepas dari keterlakasanaan kegiatan yang dilakukan oleh guru pada setiap siklus nya.

Ruang lingkup bahan kajian IPA untuk SD/MI meliputi aspekaspek berikut: Makhluk hidup dan proses kehidupannya, yaitu manusia, hewan, tumbuhan dan interaksinya dengan lingkungan, serta kesehatan., Benda/materi, sifat-sifat kegunaanya meliputi : cair, padat, dan gas dan Energi dan perubahannya meliputi: gaya, bunyi, panas magnet, listrik, cahaya dan pesawat sederhana (Mulyasa, 2008). Menurut Hamruni metode Cart Sort merupakan kegiatan kolaboratif yang bisa digunakan untuk mengajarkan konsep, penggolongan sifat, fakta tentang suatu objek, atau mengulangi informasi (Hariyanto, 2013). Kekurangan dalam metode Card Sort ini banyak menyita waktu karena menyiapkan model pembelajaran terlebih dahulu (Sari, 2018). Solusi untuk mengatasi kelemahan metode Card Sort dapat meminimalisir dengan persiapan yang matang seperti pembuatan media, RPP, dan instrumen lain yang dibutuhkan (Wulandari, 2018). Hasil belajar merupakan penilaian terhadap tingkat keberhasilan siswa mencapai tujuan yang telah ditetapkan dalam sebuah program (Muhibbin Syah, 2013).

Peneliti mendeskripsikan dan menganalisis data yang sebelumnya telah di uji hipotesis oleh penelitian sebelumnya untuk dibandingkan dan menarik kesimpulan. Adapun penemuan yang berhasil dihimpun, diantaranya:

Pertama, Dalam penelitian terdahulu, sebuah penelitian yang di lakukan oleh I Ketut Sanjaya, Ndara Tanggu Renda, Putu Nanci Riastini yang berjudul "Penerapan Strategi Pembelajaran Card Sort untuk Meningkatkan Aktivitas dan Hasil Belajar IPA" dengan kesimpulannya, Penerapan strategi pembelajaran Card Sort dapat meningkatkan hasil belajar belajar IPA siswa kelas V semester I SD N 3 Tukadmungga, Kecamatan Buleleng, Kabupaten Buleleng. Pada siklus I, persentase rata-rata hasil belajar siswa sebesar 72,85\% berada pada kategori "sedang". Selanjutnya pada siklus II, persentase rata-rata aktivitas belajar IPA siswa sebesar 82,61\% berada pada kategori "tinggi (I Ketut Sanjaya, Ndara Tanggu Renda, 2016).

Dari penjelasan di atas dapat ditarik kesimpulan bahwa strategi yang tepat merupakan faktor pendukung dalam meningkatkan kemampuan hasil belajar siswa. Menurut Oemar Hamalik "Hasil belajar merupakan 
bukti terjadinya perubahan tingkah laku seseorang yang tampak pada aspek - aspek seperti; aspek pengetahuan, pengertian, kebiasaan, keterampilan, apresiasi, emosional, hubungan sosial jasmani, etis budi pekerti dan sikap (Oemar Hamalik, Proses Belajar Mengajar, (Jakarta: PT Bumi Aksara, 2005), Hal 30). Indikator hasil belajar menurut Benjamin S.Bloom dengan Taxonomy of Education Objectives membagi tujuan pendidikan menjadi tiga ranah, yaitu ranah kognitif, yakni semua yang berhubungan dengan otak serta intelektual. afektif, semua yang berhubungan dengan sikap, dan sedangkan psikomotorik (Nugiantoro, 1998).

Kedua, penelitian yang dilakukan Jumiati L yang berjudul "Penerapan Metode Pembelajaran Aktif Tipe Card Sort untuk Meningkatkan Hasil Belajar IPA pada Siswa Kelas V SDN 241 Barugae Kecamatan Bulukumpa Kabupaten Bulukumba", dengan kesimpulannya Metode Pembelajaran Aktif tipe Card sort setelah diterapkan dengan baik pada siswa kelas V SDN 241 Barugae Kecamatan Bulukumba Kabupaten Bulukumba dapat meningkatkan hasil belajar IPA siswa. Hal ini dapat dibuktikan dari hasil belajar dan jumlah siswa yang memenuhi KKM pada siklus I dan meningkat pada siklus II (Jumiati, 2016).

Dari penjelasan di atas, maka peneliti simpulkan bahwa adanya peningkatan hasil belajar ketika menggunakan metode pembelajaran dengan tipe card sort sesuai dengan dua para peneliti terdahulu. Bagian ini merupakan bagian utama artikel hasil penelitian dan biasanya merupakan bagian terpanjang dari suatu artikel. Hasil penelitian yang disajikan dalam bagian ini adalah hasil "bersih". Proses analisis data seperti perhitungan statistik dan proses pengujian hipotesis tidak perlu disajikan. Hanya hasil analisis dan hasil pengujian hipotesis saja yang perlu dilaporkan. Tabel dan grafik dapat digunakan untuk memperjelas penyajian hasil penelitian secara verbal. Tabel dan grafik harus diberi komentar atau dibahas.

\section{KESIMPULAN}

Proses pembelajaran IPA melalui penerapan strategi card sort sangat membantu para siswa untuk memahami materi, kemampuan kerjasama siswa berkembang, berpikir lebih kritis dan mendapatkan pengalaman secara langsung terkait materi. Pembelajaran lebih menyenangkan dan bermakna, karena di dalam proses pembelajaran melibatkan siswa, baik secara fisik maupun mental. Sehingga antusiasme serta keaktifan siswa terlihat dalam mengikuti setiap langkah kegiatan yang diikutinya. Selain itu, dengan menggunakan media pembelajaran kartu-kartu yang dibuat semenarik mungkin, membuat stimulus/daya tarik bagi siswa lebih bersemangat dalam belajar.

Hasil belajar IPA siswa kelas III pada setiap siklus sangat baik. Dengan penerapan strategi pembelajaran card sort pada pembelajaran IPA sangat membantu dalam memperbaiki hasil belajar siswa dengan mengaktifkan siswa selama belajar sehingga materi yang diajarkan lebih mudah dipahami. Hal ini dapat dibuktikan dengan hasil nilai rata-rata kelas III pada setiap siklus mengalami peningkatan. Nilai rata-rata siklus I 66,53, pada siklus II 73,07 dan siklus III 81,34.

Peningkatan hasil belajar IPA sangat baik. Hal ini ditunjukan dengan adanya ketuntasan individual dalam belajar pada setiap siklusnya. Dimana pada pra siklus 38,46\%, naik menjadi 50\% dengan kenaikan 11, 54\% pada siklus I, pada siklus II 76,92\% dengan kenaikan 26,92\% dan pada siklus III $100 \%$ dengan kenaikan $23,08 \%$.

\section{DAFTAR PUSTAKA}

Aqib, Z. (2009). Penelitian Tindakan Kelas. Yrama Widya.

Fauzi, M. (2013). Ragam Metode Mengajar. DIVA Press.

Hariyanto, W. dan. (2013). Pembelajaran Aktif Teori Dan Asesmen, Kedua Edition. PT Remaja Rosdakarya,.

I Ketut Sanjaya, Ndara Tanggu Renda, P. N. R. (2016). Penerapan Strategi Pembelajaran Card Sort Untuk Meningkatkan Aktivitas Dan Hasil Belajar Ipa. Mimbar PGSD, 3(6), 3.

Jumiati. (n.d.). Jumiati L: Pembelajaran Aktif Tipe Card Soft 1. 1-10. 
2107 Meningkatan Hasil Belajar Siswa Melalui Penerapan Strategi Pembelajaran Card Sort di Madrasah Ibtidaiyah - Deni indrawan, Ichsan

DOI: https://doi.org/10.31004/edukatif.v3i4.1033

Mahmud. (2008). Penelitian Tindakan Kelas Teori dan Praktik. Tsabita.

Muhibbin Syah. (2013). Psikologi Belajar,. PT Raja Grafindo.

Mulyasa, E. (2008). Kurikulum Tingkat Satuan Pendidikan. PT Remaja Rosdakarya.

Nugiantoro, B. (1998). Dasar-dasar Pengemangan Kurikulum Sekolah. BPFE.

Rahma., A. A. \& E. (1998). Ilmu Alamiah Dasar. Bumi Aksara.

Raisul, M. (2006). Active Learning 101 Cara Belajar Aktif. Nusa Media.

Sari, N. (2018). Peningkatkan Hasil Belajar Pkn Melalui Metode Card Sort Pada Siswa Sd Negeri 050748 Pangkalan Berandan Tahun Ajaran 2016-2017. Jurnal Tabularasa PPS UNIMED, 15(1).

Sudjiono, A. (2005). Pengantar Statistik Pendidikan. Raja Grapindo Persada.

Surya. (2010). Pengaruh Motivasi Belajar IPA Siswa Terhadap Hasil Belajar. EDUKATIF : Jurnal Ilmu Pendidikan, 1(3), 280-286. https://edukatif.org/index.php/edukatif/index\%0APENGARUH

Surya, M. (2003). Psikologi Pembelajaran dan Perencanaan. CV Maha Putra.

Tatang S. (2012). Ilmu Pendidikan. Pustaka Setia.

Wahyuningtyas, R., \& Sulasmono. (2020). Pentingnya Media dalam Pembelajaran Guna Meningkatkan Hasil Belajar di Sekolah Dasar. Edukatif: Jurnal Ilmu Pendidikan, 2(1), 23-27. https://doi.org/10.31004/edukatif.v2i1.77

Wisudawati, A. W. (2014). Metodologi Pembelajaran IPA. Bumi Aksara.

Wulandari, E. N. H. dan T. (2018). Penggunaan Metode Card Sort Untuk Meningkatkan Keaktifan Siswa dalam Pelajaran IPS Kelas VIII E SMP Negeri 1 Majalengka,. JIPSINDO, 5(1).

Yani, A. T. (2012). Pembaharuan Pendidiikan. Humaniora. 